\title{
REDESENHANDO AS FRONTEIRAS DO GOSTO: ESTUDANIES DE MÚSICA E DIVERSIDADE MUSICAL
}

\section{Elizabeth Travassos \\ Universidade do Rio de Janeiro - Brasil}

Resumo: $O$ artigo examina aspectos da diversidade de perfis culturais dos estudantes de música do Instituto Villa-Lobos da Universidade do Rio de Janeiro (Uni-Rio). Procura-se mapear as preferências por determinados repertórios, relacionando-as com os cursos freqüentados. Discute-se também a reivindicação de reconhecimento para a música popular, formulada por vários alunos, e a forma como vêem suas experiências profissionais.

Palavras-chave: estudantes de música, etnografia da música, música popular.

Abstract: The article addresses the cultural diversity among students of music taking courses at the Instituto Villa-Lobos (University of Rio de Janeiro music school). It attempts to describe the musical repertoires chosen by the students and to correlate them with the choice of music courses and professional experiences. Special attention is given to the students' campaigning for the popular music.

Keywords: music students, musical ethnography, popular music.

Escrevendo sobre as escolas superiores de música nos Estados Unidos, Bruno Nettl constata que elas se dedicam quase que exclusivamente à música "clássica". Instituições governadas por deuses (os "grandes mestres da música"), elas têm seus textos sagrados (um repertório canônico), rituais e corpo de sacerdotes. A descrição registra mudanças recentes que vêm transformando as 
escolas em "pontos de encontro para potencialmente todas as músicas" (Nettl, 1995, p. 5). ${ }^{1}$ Se os clássicos continuam ocupando posição central e recebendo a reverência que a cultura musical do ocidente exige, as escolas assistem ao fortalecimento de setores dedicados a deuses menores, concorrentes, ou ao crescimento da atitude profana que questiona a existência mesma de cânones. Tornam-se crescentemente lugares de convergência e colisão de muitas músicas, entre elas a música popular, que já foi objeto de proibição (Nettl, 1995, p. 82). ${ }^{2}$ Do banimento passou-se à interação institucionalmente mediada que preserva a hierarquização na forma de círculos concêntricos, ocupados por tipos de música cuja legitimidade decresce à medida que se afastam do centro. No todo, as escolas são mais adequadamente descritas como mosaicos de repertórios justapostos do que como melting pots nos quais as misturas são possíveis.

A leitura da etnografia de Nettl inspira a apreciação comparativa entre sistemas classificatórios vigentes nas escolas norte-americanas, de um lado, e entre estudantes do Rio de Janeiro, de outro. Tomando como ponto de partida o material empírico produzido por uma investigação em curso sobre os perfis culturais dos estudantes de música do Instituto Villa-Lobos da Universidade do Rio de Janeiro (Uni-Rio), exploro, neste artigo, algumas idéias sobre a hierarquização de repertórios, práticas e carreiras musicais. Conforme parece lícito concluir dos dados, o IVL atrai uma clientela com diferentes experiências musicais e relações com a cultura musical erudita. A diversidade de experiências dos alunos sinaliza, antes de mais nada, a impossibilidade de tomá-los como um grupo culturalmente uniforme, não obstante sua condição presente de estudantes universitários de música, majoritariamente membros de famílias das classes médias. Neste sentido, o corpo de alunos constitui um campo privilegiado para a investigação das fronteiras culturais do gosto musical.

\footnotetext{
Por música clássica entende a tradição escrita, majoritariamente européia, do período compreendido entre aproximadamente 1720 e 1930, também chamada música da "common-practice".

$2 \mathrm{O}$ autor data dos anos 80 algumas das referidas mudanças: "Some of the energy of the Heartland music school, at least before the late 1980s, was devoted to protecting students from bad music and promulgating what is often labeled as 'serious' music (or seriously called 'good music'), or not so facetiously, 'real' music" (id. ibid., p. 83). Em 1950, diz ele, a escola era definitivamente unimusical.
} 
Muitos estudantes engajam-se na discussão das hierarquias no campo musical, reivindicando maior atenção para repertórios e autores classificados como populares. A reivindicação apóia-se em critérios de qualidade válidos para a música erudita, implicitamente tomados como universais. Dessa forma, tende-se a reiterar a operação classificatória dominante, no Brasil, que cinde o universo da música em dois grandes campos hierarquicamente relacionados. Cabe perguntar até que ponto a reivindicação traduz uma demanda pela relativização dos valores estéticos ou um realinhamento de repertórios que deixa intocada a relação hierárquica entre "música artística" e as demais. ${ }^{3}$

Embora a investigação não tome a instituição escolar como objeto etnográfico, e sim seus estudantes, ela tangencia alguns aspectos da organização do IVL que entram como dados subsidiários. Os estudantes não estão sozinhos na discussão da hierarquia entre tipos de música. Há muito debate, contemporaneamente, em torno do "cânone" musical, dentro e fora dos perímetros acadêmicos, gerando bandeiras que podem ser empunhadas por críticos do elitismo e do eurocentrismo costumeiramente associados à definição de uma música "artística". Várias preocupações manifestas no debate interessam-me de perto, mas a investigação não ambiciona localizar as causas da perpetuação de desqualificações no terreno da música. A avaliação dos cursos do IVL também não está em jogo, mesmo quando os alunos entrevistados se dispõem espontaneamente a ajuizar a qualidade da formação musical propiciada na escola. Por urgentes que sejam essas tarefas, a pesquisa não responde a um objetivo pragmático de diagnosticar problemas para propor soluções ou subsidiar futuras providências de melhoria. Conseqüentemente, ela dificilmente servirá a leituras que pretendam conhecer o estado da educação musical. A opção etnográfica baseia-se na convicção de que a relevância das questões culturais não se confunde com a problematização do ensino de artes e música em nível superior.

\footnotetext{
Richard Middleton (1990, p. 124) observa, com relação à produção musicológica que se volta para a música popular sem rever as premissas da "mainstream musicology": "Jazz is the classic case of the legitimation of a once disreputable music. In recent years, much ragtime research has trod a similar path. The key to the approach is that this is 'art', and the analytic and aesthetic criteria developed in classical musicology can be applied.” No conjunto de forças sociais capazes de elevar repertórios à condição de arte, está também a legitimação que se processa pela via da incorporação no horizonte de preocupações acadêmicas.
} 
A literatura brasileira que discute as relações entre música popular e educação formal é relativamente extensa e serve-se, com freqüência, da comparação entre processos formais e informais de ensino e aprendizagem. A transmissão de saberes musicais é particularmente fértil para a observação dos processos pedagógicos em meios populares e espaços não-institucionalizados, dada a desproporção entre setores da população que têm acesso a algum tipo de educação musical formal e a vitalidade das práticas musicais entre aqueles, muito mais numerosos, a quem é vedada qualquer chance de "estudar música". A exclusão aí parece ser ainda mais acentuada que na educação geral, sabidamente distante da democratização real. O recurso à literatura que trata da educação musical informal em meios populares é limitado porque interessam-me, sobretudo, os perfis culturais dos estudantes de música do IVL - que já passaram pelos processos de seleção e foram considerados pelo sistema de ensino capacitados para os estudos superiores de música. ${ }^{4}$

A existência de tais processos coloca-nos diante de indivíduos pertencentes às camadas beneficiadas tanto por estudos secundários eficientes face à seleção do vestibular quanto por estudos musicais prévios, em conservatórios, cursos preparatórios ou por intermédio de professores particulares. Embora a população estudantil não seja homogênea do ponto de vista da orientação cultural das famílias, seus membros submetem-se, neste momento, ao processo de educação musical formal e oficial. Esta experiência não exclui outras formas de aprendizado, simultâneas, nem anula necessariamente as anteriores, mas marca definitivamente os que a ela se submetem como músicos formados na escola.

Uma vez que se falou de música popular, outros esclarecimentos são necessários. Esta expressão remete, habitualmente, a uma lista de produtos e seus respectivos produtores. Definições baseadas em critérios sem efeito

4 Isso abrange uma seleção ampla com base na educação geral e uma seleção específica efetuada por meio dos testes específicos de habilidade musical, os quais variam conforme o curso a que se dirige o vestibulando. Os cursos do IVL são: Bacharelado em Música (Canto, Instrumentos - clarineta, contrabaixo, fagote, flauta transversa, oboé, piano, trompa, viola, violão, violino, violoncelo -, Composição, Regência, Música Popular) e Licenciatura em Educação Artística - Habilitação em Música. Os candidatos à Licenciatura, Canto, Instrumentos e Música Popular Brasileira fazem provas de percepção - subdividida em teoria, ditado e solfejo - e execução musical. Os candidatos à Composição e Regência fazem provas de percepção mais difíceis (ditado a duas vozes), além de provas de harmonia, história da música, leitura à primeira vista e piano. Dados extraídos do Roteiro do Candidato publicado pela Fundação Cesgranrio para orientar os inscritos no concurso vestibular de 1999.

Horizontes Antropológicos, Porto Alegre, ano 5, n. 11, p. 119-144, out. 1999 
substantivador, como os que foram bastante discutidos por folcloristas e etnomusicólogos, enfatizam os processos de criação ("coletiva", a partir de "fórmulas" e da contínua variação de material preexistente etc.) e de transmissão (oral/aural, por meio de contatos interpessoais etc.). Contudo, como já observaram vários autores, esses processos não estão ausentes da música erudita. ${ }^{5}$ Ademais, a análise da gênese histórica da noção de cultura popular mostra que esta é, antes de tudo, uma categoria erudita (Chartier, 1995). Resulta de uma classificação de níveis de cultura elaborada por intelectuais, tingida de componentes políticos (o "povo" aparece como depositário de signos valorados de autenticidade e simplicidade, ameaçados pela crescente mercantilização da cultura) e sujeita a variações que ora excluem a música "urbana", ora a "comercial", ora a que é difundida em grande escala nos meios de comunicação de massa. Analogamente, a constituição de um repertório clássico e da ideologia da música "séria", "elevada", também já foi historicizada (v., por exemplo, DeNora, 1997). Esse conjunto de estudos impõe, pois, o tratamento de categorias como música popular e música erudita no âmbito de classificações histórica e culturalmente localizadas. Assim sendo, é necessário entender as classificações elaboradas pelos estudantes para saber ao que se referem quando falam de popular e erudito. Da mesma forma, impõe-se pensar não em repertórios substantivos de obras e autores, mas em lógicas de produção e recepção que operam na organização de ambientes musicais (Bourdieu, 1982).

É relativamente pequeno o número de alunos do IVL direcionados para carreiras de concertista, músico de orquestra ou conjuntos de câmara, compositor e regente. A maior parte deles já deu passos importantes no processo de constituição da identidade de músico profissional, tocando ou cantando em bares, teatros e estúdios, gravando jingles, compondo e executando trilhas sonoras. Por músico profissional entende-se aqui não só aquele que exerce atividades remuneradas, mas também aquele cuja prática, independentemente da geração de renda, se desenrola num determina do enquadramento de relações sociais que a distingue da prática de estudo (na qual o músico é aluno), de ensaio (que é preparatória da performance propriamente dita), ou de passatempo

\footnotetext{
5 Middleton (1990, p. 133) observa, com relação à definição de música folclórica adotada pelo International Folk Music Council em 1954 (“... produto de uma tradição musical que emergiu por meio do processo de transmissão oral"): "There is nothing in the whole definition which in principle could not be applied to the history of Beethoven symphony performance - or to the performance histories of music hall, the songs of Irving Berlin or rock'n'roll."
}

Horizontes Antropológicos, Porto Alegre, ano 5, n. 11, p. 119-144, out. 1999 
(que dispensa público e uma situação de performance formalizada). ${ }^{6}$ Assim, um indivíduo ou grupo que procura aproveitar todas as oportunidades de apresentação pública, sem ganho financeiro imediato, faz música profissionalmente, sobretudo se elas contribuem para tornar conhecidos seu nome e seu trabalho.

Com relação aos estudantes que já fizeram estudos musicais e têm uma identidade profissional, cabe perguntar as razões da procura pelos cursos do IVL. Embora o tema não possa ser esgotado em poucas linhas, sabe-se que estão em jogo o desejo de uma formação melhor ou mais completa, a expectativa de novas oportunidades de trabalho geradas pela ampliação da rede de contatos, o valor simbólico do diploma de terceiro grau e a ansiedade gerada pela instabilidade dos ganhos como profissional autônomo de música. No primeiro caso, o curso superior de música pode coroar uma prática profissional intensa e bem-sucedida com a sistematização escolar e a aquisição de técnicas específicas. Somando as virtudes que se atribuem ao músico popular (ouvido, bossa, capacidade de improvisação etc.) ao prestígio do conhecimento sancionado pela escola, a dupla formação proporciona para alguns alunos a realização de sua demanda por uma cultura musical plena. A aliança entre saberes erudito e popular reflete um ideal de completude particularmente importante para os artistas na era moderna. ${ }^{7}$ Numa perspectiva mais instrumental, o diploma é uma esperança de estabilização financeira porque possibilita os vínculos empregatícios com escolas oficiais.

Além do direcionamento majoritário dos estudantes, o IVL implantou, recentemente, um Bacharelado em Música Popular Brasileira (data de 1998 a entrada da primeira turma), o que contribui para fazer da instituição uma escola atípica, posta em comparação, freqüentemente, com escolas ditas mais tradicionais e menos abertas à música popular. É preciso lembrar que um dos argumentos favoráveis ao novo bacharelado foi a expectativa de efeitos saudáveis que a existência desta carreira teria sobre o curso de Licenciatura, "inchado"

\footnotetext{
6 A etnomusicologia tem chamado a atenção para os benefícios da abordagem dos contextos de performance (v. Seeger, 1987 entre outros). A noção é útil, neste caso, por permitir distinguir práticas profissionais, diletantes, ou de estudo e ensaio, a partir do contexto de relações sociais. Tal contexto afeta também o modo de recepção da música executada. Em outras palavras, não é necessariamente a qualidade intrínseca do repertório e de sua interpretação que permite cruzar a linha que separa o estudante do profissional músico.

7 Ver as observações de José Jorge de Carvalho (1992) sobre o ideal de uma totalidade integrada pelas tradições clássica e popular.
} 
por alunos que não escolheram a carreira de professor e, conseqüentemente, prejudicado em seus objetivos precípuos. O curso atraía os vestibulandos que não se encaixavam nos cursos de instrumento existentes, tornando-se, por força da escolha por eliminação, abrigo de guitarristas, saxofonistas, bandolinistas, pianistas populares, arranjadores. Ou abrigo de músicos que encaram o magistério como tábua de salvação, garantia de uma renda mínima, mas que investirão, de fato, nas atividades mais valorizadas de composição ou de performance. ${ }^{8}$

A realidade do IVL faz saltar aos olhos a peculiaridade da categoria música popular, que, neste caso, não designa a produção das camadas sociais populares. Tampouco indica a produção que, independentemente de sua origem, se destina ao "grande público" pela via dos meios de comunicação de massa. De fato, os estudantes fazem sérias restrições à música popular cujo sucesso se traduz em índices de vendagem. Seria então aquela que prescinde da escrita, seja como modo de composição, seja como modo de registro e transmissão - portanto a música dos que "tocam de ouvido", dos que não "sabem música"?? Tanto o critério da oralidade quanto o da legitimidade social dos repertórios (medida pelo grau de absorção pelas instituições escolares) jogariam o Bacharelado em Música Popular do IVL num paradoxo - ser a escola que ensina aquilo que não se aprende na escola.

Música popular parece ser, então, um lugar vazio a ser ocupado por coisas diversas, em tipologias que devem ser contextualizadas. A importância desse lugar como encaminhamento profissional no campo artístico para jovens das classes médias do Rio de Janeiro deve ser compreendida no quadro da organização do setor musical como um todo, com seu mercado de recitais e concertos bastante estrangulado - embora prestigiado pela sociedade -, mecenato estatal limitado, uma indústria musical poderosa e muitos circuitos "alternativos" que incluem desde selos independentes até bares e casas noturnas com programação musical ao vivo.

8 Dados gerais sobre o alunado do IVL estão anexos (Distribuição dos alunos por curso e por sexo em 1998/99).

9 É também Nettl (1985) quem observa a equivalência entre "saber música" e "saber 1er e escrever música", isto é, ter competência no código gráfico de representação do som (válido, basicamente, para o período da "common practice"). 
O exame de dados obtidos por meio de um questionário, aplicado tão amplamente quanto possível, e de entrevistas com um número restrito de alunos permite desenvolver os argumentos acima. ${ }^{10}$ As perguntas do questionário desencadearam o uso de categorias que designam tipos de música, a referência a práticas - tais como tocar um instrumento numa gravação em estúdio, dar recitais, fazer transcrições para compositores que não detêm a técnica da escrita musical etc. - e a instituições ou grupos que absorvem músicos - bandas, orquestras, coros etc. A tabela 1 resume os tipos de repertório mencionados (primeira coluna), o número de ocorrências dos tipos (segunda coluna), os cursos freqüentados pelos estudantes (terceira coluna) e suas atividades (quarta coluna). Deixamos de registrar, aqui, as menções à atuação como professor de música (particular e/ ou em escolas), a mais bem distribuída entre todos os estudantes.

${ }_{10}$ A bolsista de IC Vera Alves de Andrade preparou um questionário para colher dados sobre as atividades profissionais dos estudantes. Aperfeiçoado após um balão de ensaio, foi aplicado a mais de uma centena de alunos. O questionário indaga o tipo de repertório praticado, como instrumentista ou cantor, e os "locais" dessa prática, dando as alternativas: bar, restaurante, estúdio, teatro, casa noturna, orquestra, coro, banda (as de maior ocorrência no balão de ensaio) e outras. Faço uso de 89 questionários preenchidos que representam $22,3 \%$ da população do IVL em 1999. As entrevistas, por sua vez, são em número reduzido e focalizam, a partir de poucas perguntas, os contatos remotos do indivíduo com a música, em família ou com amigos, os estudos musicais prévios à entrada na escola, as atividades e os projetos para o futuro.

${ }^{11}$ Divergências no entendimento do questionário tiveram conseqüências sobre as respostas. O campo "tipo de repertório" não foi preenchido por 12 alunos, dos quais 11 não informaram nenhuma atividade profissional; um, porém, participa de um coro (considerado talvez não-profissional); outro menciona transcrição / teatro infantil como atividades profissionais, sem discriminar o tipo de repertório (talvez porque o campo foi subordinado ao registro de atuações como instrumentista ou cantor). Apesar das variações de leitura, as respostas fizeram emergir tipos de música reconhecidos conforme categorias que não foram dadas de antemão.

Horizontes Antropológicos, Porto Alegre, ano 5, n. 11, p. 119-144, out. 1999 
Tabela 1. "

\begin{tabular}{|c|c|c|c|}
\hline Tipo de repertório & $\mathbf{N}$ & Cursos & Atuação profissional \\
\hline "erudito", "clássico" & 8 & $\begin{array}{l}\text { Canto(2) Comp(1) } \\
\text { Lic(1) Oboé(1) } \\
\text { Piano(1) Viola(1) } \\
\text { Violino(1) }\end{array}$ & coro(3) nenhuma(1) orquestra(3) teatro(1) \\
\hline $\begin{array}{l}\text { "erudito e modernos } \\
\text { russos" }\end{array}$ & 1 & Piano(1) & nenhuma(1) \\
\hline $\begin{array}{l}\text { "barroco e medieval", } \\
\text { "renascentista" }\end{array}$ & 2 & Licenciatura(2) & coro(1) quarteto vocal(1) \\
\hline $\begin{array}{l}\text { "erudito/popular", "MPB } \\
\text { ao erudito", "clássicol } \\
\text { rock", "variado" }\end{array}$ & 16 & $\begin{array}{l}\text { Comp(1) Flauta(3) } \\
\text { Lic(8) Regência(1) } \\
\text { Violão(1)Violino(1) } \\
\text { Violoncelo(1) }\end{array}$ & $\begin{array}{l}\text { banda(6) banda reggae(1) bar(1) } \\
\text { casamento(3) casa noturna(4)coro(3) } \\
\text { estúdio(8) música de câmara(2) orquestra(6) } \\
\text { Orquestra de Violões da Uni-Rio(1) } \\
\text { restaurante(2) teatro(6) transcrição(1) trilhas } \\
\text { TV(1) técnico de áudio (1) }\end{array}$ \\
\hline "popular" & 6 & Lic(5) Violão(1) & $\begin{array}{l}\text { banda(1) bar(1) casa not(1) coro(2) } \\
\text { estúdio(2) orq.(1) Orq Viol. Uni-Rio(3) } \\
\text { rest(2) teatro(1) }\end{array}$ \\
\hline $\begin{array}{l}\text { "MPB", "choro", } \\
\text { "bossa-nova","samba", } \\
\text { "popular latino" "jazz", } \\
\text { "pop", "soul", "gospel", } \\
\text { "ffunk", "frevo", "música } \\
\text { de mídia", "folclore", } \\
\text { combinações entre estes }\end{array}$ & 25 & $\begin{array}{l}\text { Comp(4) Flauta(2) } \\
\text { Licenciatura(18) } \\
\text { MPB(1) }\end{array}$ & $\begin{array}{l}\text { banda(1) banda própr.(7) acompanhamento } \\
\text { cantora(1) bar (14) casa not.(14) clube(1) } \\
\text { coro(3) digitação partituras(1) estúdio(8) } \\
\text { grupo de choro(3) mamulengo(1) orquest. } \\
\text { (2) restaur.(9) teatro(8) trilhas(1) }\end{array}$ \\
\hline "brasileiro" & 2 & Lic(1) Violão(1) & $\begin{array}{l}\text { bar(1) casa not(1) estúdio(1) grupo } \\
\text { contadores de estórias(1) orq (1) rest(1) } \\
\text { teatro(1) transcrição(1) }\end{array}$ \\
\hline "instrumental" & 3 & Lic(2) Violão(1) & $\begin{array}{l}\text { banda pr.(1) bar(2) estúdio (1) gravadora (1) } \\
\text { Orq Viol/Uni-Rio( } 1 \text { ) }\end{array}$ \\
\hline "próprio", “inédito" & 3 & $\operatorname{Lic}(3)$ & $\begin{array}{l}\text { banda católica(1) bar(1) casa not(1) coro(2) } \\
\text { estúdio(1) orq(1) primeiro } C D(1) \text { teatro(1) }\end{array}$ \\
\hline $\begin{array}{l}\text { "erudito/sacro", } \\
\text { "sacro","religioso" }\end{array}$ & 11 & $\begin{array}{l}\text { Canto(1) Comp(1) } \\
\text { Lic(7) Piano(2) }\end{array}$ & $\begin{array}{l}\text { banda evang.(1) coro(10) ministro de mús. } \\
\text { (1) pian.igrej.(1) transc.(1) }\end{array}$ \\
\hline em branco & 12 & $\begin{array}{l}\text { Comp (2) Lic (6) } \\
\text { Piano (3) Reg (1) }\end{array}$ & $\begin{array}{l}\text { coro (1) transcrição/ teatro infantil (1) } \\
\text { nenhuma(11) }\end{array}$ \\
\hline Totais & 89 & $\begin{array}{l}\text { Canto(3) Comp(9) } \\
\text { Flauta(5) Lic(53) } \\
\text { MPB(1) Oboé(1) } \\
\text { Piano(7) Reg(2) } \\
\text { Viola(1) Violão(5) } \\
\text { Violino(2) }\end{array}$ & $\begin{array}{l}\text { acomp. cantora(1) banda(8) banda catól.(1) } \\
\text { ban.evang.(1) banda reggae(1) banda próp. } \\
\text { (8) bar(20) casam(3) casa not(21) clube(1) } \\
\text { cont.est.(1) coro(25) digit.(1) estúdio(21) } \\
\text { grav.(1) gr.choro (3) mús.câm.(2) min. } \\
\text { mús.(1) orq.(14) OrqViol/Uni-Rio(5) pian. } \\
\text { igreja(1) } 1^{\circ} \mathrm{CD}(1) \text { quart vocal(1) rest(14) } \\
\text { teatro(18) téc audio(1) transc.(4) trilhas(2) } \\
\text { mamulengo(1) nenhuma(13) }\end{array}$ \\
\hline
\end{tabular}

Horizontes Antropológicos, Porto Alegre, ano 5, n. 11, p. 119-144, out. 1999 
O agrupamento das categorias na tabela foi orientado pelas preocupações deste artigo. Estudantes concentrados num repertório genericamente erudito ou clássico foram separados dos que mencionam períodos históricos da música européia. Outros têm prática eclética que inclui repertórios eruditos e populares ao mesmo tempo, ou que são ditos simplesmente "variados". Alguns dedicam-se genericamente ao popular, mas a maioria prefere nomear gêneros e combinações entre eles (samba, choro, jazz, bossa-nova etc.). Até este ponto, está latente uma polarização entre erudito e popular como instrumento de reconhecimento de repertórios. Destaquei as ocorrências, em menor número, das categorias (repertório) "brasileiro", "próprio", "inédito" e "instrumental", pois sugerem outras preocupações e oposições subjacentes (brasileiro/estrangeiro, próprio/alheio, instrumental/“canção"). Por fim, emerge com nitidez o grupo especializado em música religiosa, composto integralmente de fiéis de igrejas protestantes tradicionais ou evangélicas (são protestantes, batistas, adventistas, presbiterianos, evangélicos).

\section{Experiências musicais e musicalizadoras}

Temporariamente oculta sob a identidade de estudante de música, a multiplicidade de experiências anteriores revela-se no contato com os alunos. Aparentemente nivelados pelas provas de habilidade específica, eles chegam à escola munidos de bagagens tão distintas entre si quanto a do filho de músicos respeitados no meio artístico e acadêmico, cujo convívio com obras e autores "sérios" começou precocemente; a do jovem a quem a família ofereceu aulas de música como parte "natural" da educação geral; a de um outro que adotou o violão, ou a guitarra, graças ao estímulo dos colegas de escola ou do bairro, grupo de pares no qual a oralidade regia toda a prática e que dispensava a aprovação da competência por parte de uma autoridade externa. Neste último caso, a aquisição posterior de domínio da escrita pode levar o estudante a minimizar a importância das vivências "tocando de ouvido", sobretudo quando encaminhado para o universo da música culta. Um depoente afirmou que seus estudos musicais tiveram início na idade adulta, referindo-se assim à vivência musical na juventude: "Comecei adulto. De vez em quando rolava uma flautinha doce, até que violão eu tocava um pouquinho" (aluno de Comp.). O fato de seus amigos tocarem flauta doce e violão despertou sua curiosidade por instrumentos que passou a tocar com base em um aprendizado informal que 
não é lembrado - ou cuja lembrança não se organiza num relato descritivo de etapas e seus conteúdos.

O investimento familiar na cultura musical ocorre, em alguns casos, sem qualquer expectativa de profissionalização futura no campo da música, um resquício da educação humanística burguesa que teve seu apogeu no século passado. ${ }^{12}$ Tanto filhos de sexo masculino quanto feminino recebem educação musical, entendida como necessária a uma formação integral que não prescinde de investimento na cultura. No caso das moças, sobretudo nas classes médias, tocar piano ainda é parte quase obrigatória da educação, fenômeno que pode parecer anacrônico à primeira vista, face às transformações na representação tradicional dos gêneros e no valor atribuído à prática pianística diletante. Por isso, ao mesmo tempo em que as famílias de algumas estudantes entrevistadas providenciaram aulas de piano para suas filhas, não se decepcionaram quando elas demonstravam uma queda de interesse pelo instrumento. Afinal de contas, não se tratava de dar às filhas o piano como ofício e sim o verniz cultural necessário. Se as aulas de piano são consideradas desejáveis, a compra de um instrumento, para algumas famílias, pode significar um gasto que deve ser ponderado: "E meu pai dizia assim: 'é fogo de palha', que ele não ia dar piano coisa nenhuma", conta uma estudante de Composição. A escolha mesma de uma carreira artística não está, às vezes, dentro do horizonte de possibilidades profissionais:

... acho que porque não tinha ninguém na família, faculdade de música, assim, não era uma coisa que fazia parte da minha realidade, eu mal sabia que existia e eu não me imaginava trabalhando com música [...]. Eles não viam um curso de artes - qualquer curso ligado à área artística - como um curso de graduação, superior. Ficavam me perguntando: você vai viver de quê? vai trabalhar com quê? (aluna de Composição).

Paralelamente, famílias que fizeram questão de dar a seus filhos a chance de "saber música" preocuparam-se quando as atividades musicais ameaçaram

12 Tal concepção de educação, segundo alguns autores, perde o sentido com a mercantilização plena da música, alcançada no estágio capitalista da indústria cultural: “... the widespread practical knowledge of music which comes from its educated amateur practice has been displaced and demoted. It is part of this syndrome that the integral place occupied by music in liberal humanist education has been lost, and music has become an increasingly isolated technical study." (Chanan, 1994, p. 8).

Horizontes Antropológicos, Porto Alegre, ano 5, n. 11, p. 119-144, out. 1999 
tornar-se mais importantes do que os estudos que garantem um diploma de nível superior respeitável e capaz de possibilitar alguma segurança financeira:

Porque o meu pai fez questão que eu fizesse algum curso superior qualquer, porque eu queria fazer vestibular pra Escola de Música, ele não deixou, psicologicamente, era pressão danada, e fizemos um acordo e tal que eu faria uma faculdade qualquer e ele me ajudaria a estudar música (aluno de Regência).

De vez em quando, mas muito raramente, meu pai chega e fala se eu não queria fazer uma outra faculdade, de outra coisa... [...] Eles têm medo porque música é uma profissão meio incerta, tem vezes que você pode estar com dinheiro e outras não, você pode estar ganhando bem e outras vezes não estar, você trabalha como autônomo... (aluno da Licenciatura).

A ansiedade paterna reproduz-se nos próprios estudantes à medida que cresce sua familiaridade com o mercado, contexto no qual o vínculo empregatício em escolas representa uma alternativa válida de estabilização financeira:

Todo mês a gente pensa: será que mês que vem vai dar? Esse que é o problema, por isso que eu acho que esse diploma de Licenciatura, acho importante, porque eu, pelo menos, com trinta anos, não estou mais a fim de ter essa preocupação. (aluna da Licenciatura).

São raros os estudantes do IVL que, ao discorrer sobre seus projetos e perspectivas futuras, não manifestam qualquer preocupação com a instabilidade financeira, não se sentem pressionados a testar sua capacidade de ganhar a vida como músicos e têm planos de continuar os estudos ainda por bastante tempo - por exemplo, em cursos de pós-graduação de sua escolha, no exterior. Membros de famílias das elites que mantêm vínculos com círculos intelectuais e artísticos, não precisam persuadir seus pais da legitimidade social de um diploma na área de artes e, conseqüentemente, dispensam a perspectiva pragmática que avalia a Licenciatura como curso útil. Munidos de recursos sociais e culturais que possibilitam a segurança íntima para assumir e sustentar ambições elevadas, tendem a escolher as carreiras "nobres" de compositor ou regente e parecem situar-se à distância do sentimento de vulnerabilidade financeira comum entre seus colegas. 
Há também aqueles, vindos de ambientes distantes do cultivo das artes, ou simplesmente das expectativas de dar aos filhos maior proximidade com a cultura legítima, para os quais a entrada na escola constitui quase um choque cultural. Subitamente dão-se conta de que, diferentemente dos seus colegas, não conheciam sequer o nome dos professores de instrumento com quem iriam estudar - às vezes, concertistas ou mestres cuja notoriedade no meio acadêmico e da música culta atrai muitos bacharelandos de instrumentos. A diferença entre sua trajetória musical anterior e a de seus colegas é estimada então em função de níveis: “... Lá [o conservatório no qual estudou] não é aquele nível, entendeu?” (aluno de Violão). Para os poucos estudantes vindos das baixas camadas médias, assim como para os que, independentemente da renda e inserção social das famílias, não foram introduzidos ao mundo da música de concerto, a experiência escolar no IVL pode ser difícil. Sentem-se ou sentiram-se durante certo tempo deslocados e relatam o impacto do desconhecimento dos códigos estéticos da escola:

Meu primeiro ano de Uni-Rio foi terrível, eu peguei desgosto com o violão, porque eu tinha uma facilidade, eu chegava e tocava tranquilo, na prova eu toquei tranquilo, mas o professor me colocou tanta coisa na minha cabeça, aquela coisa de ter que ser perfeito, eu fiquei me achando o cara mais burro do mundo, e eu tinha medo [...]. (aluno de Violão).

O sucesso nos estudos musicais prévios à entrada na escola, que autorizava o desejo de dedicar-se profissionalmente à música, é abruptamente posto em xeque. Aparece o medo de errar - dramático para solistas da música de concerto -, de não estar à altura de suas ambições. Outra jovem, iniciada no piano na infância com uma professora particular que, ao lado da família, apostava nas suas qualidades de instrumentista, tomou consciência de que não possuía a técnica adequada nem conhecia o repertório certo, aquele que é considerado conditio sine qua non para a formação de um pianista. Perdeu a desenvoltura para apresentar-se em público, uma vez que nada confirmava a viabilidade de seu sonho e redirecionou a trajetória transferindo-se do Bacharelado para a Licenciatura. Episódio revelador do redimensionamento das ambições diante das possibilidades objetivas de realizá-las, a transferência tende a confirmar a reputação da Licenciatura como o curso que "pesca" alunos insatisfeitos - por diversas razões - com os bacharelados em instrumento. 
Um estudante de violão, já estabelecido no mercado como professor de música, atribui à disponibilidade de recursos econômicos a possibilidade de colocar para si a meta de ser concertista:

... seu sonho tem que estar dentro da tua realidade, se eu fosse um cara rico, talvez eu quisesse ser um violonista de nome, você tem que ver qual é a realidade de um violonista de nome; [...] ser só concertista não dá, não dá porque você não vai ganhar dinheiro, e sem dinheiro... eu teria parado de tocar violão há muito tempo, eu não teria como fazer uma faculdade... (aluno de Violão).

Sua percepção retira o peso das qualidades individuais inatas como determinantes do êxito musical, mas subestima a diferenciação propriamente cultural entre instrumentistas em formação.

Um grupo numericamente expressivo de estudantes teve iniciação musical nas igrejas protestantes e encontra nessas igrejas o principal estímulo aos estudos. ${ }^{13}$ Diferentemente dos ateus e membros de outras religiões, cuja vocação musical não tem relação necessária com a religião, os protestantes geralmente adquiriram as primeiras competências musicais nos círculos de sociabilidade e escolas ligados às igrejas que freqüentam. Na verdade, foram elas que ofereceram a alguns de seus fiéis, na ausência de qualquer estímulo proveniente da orientação cultural da família e da escola regular, a possibilidade de imaginar, para si mesmos, uma carreira musical:

Eu comecei a tocar na igreja, onde toco até hoje, eles estavam oferecendo aula de violão aos sábados, e eu tinha de 8 para 9 anos e estava fazendo aula, mas não tinha violão ainda, eu fazia numa guitarra, aí nesse meio tempo tinha um contrabaixo vazio lá, e aí comecei a tocar contrabaixo... [...] a igreja é uma escola, a igreja tem essa vantagem que você tem contato com tudo, eu toco um pouco de teclado, porque lá não tinha quem tocasse e aí eu comecei a pegar, dei meio jeito, então é uma escola, você tem outros grupos, outros conjuntos, e estavam precisando de um cara para tocar, e aí eu estava sempre em todas. (aluno de Violão).

13 Dentre os 89 estudantes, 22 são protestantes (aproximadamente 24\%); destes, 11 (50\%) fazem música sacra.

Horizontes Antropológicos, Porto Alegre, ano 5, n. 11, p. 119-144, out. 1999 
... ninguém ensinava... era 1,2,3, e vamos lá [...] eu comecei freqüentando, ouvindo, e já ia conhecendo as músicas, depois é que eu comecei a tocar, aí eu já conhecia a melodia e era mais fácil, você vai de ouvido mesmo. (aluno da Licenciatura).

As chances de tocar eram muitas e a prática incitada sem exigências técnicas ou de preparo anterior que pudessem inibir um debutante. Conforme as entrevistas com estudantes revelam, as igrejas são espaços musicais inclusivos que não colocam pré-requisitos técnicos rigorosos. Aí a regra parece ser o fomento à participação que, por sua vez, promove a prática musical. A alimentação recíproca dos dois é prontamente captada por um aluno, ao explicar que, quanto mais ia às igrejas evangélicas, mais tocava, e quanto mais era chamado para tocar, mais ia às igrejas:

... já fui em várias igrejas evangélicas e isso ajudou no meu desenvolvimento musical, porque eu tocava muito em igreja, igreja era uma coisa constante, toda semana eu estava lá tocando, aliás uma coisa influencia a outra, porque por eu tocar, eu ia mais à igreja e indo mais à igreja, eu tocava [mais]... (aluno da Licenciatura).

\section{Tipos de repertório e hierarquização no campo da música}

À primeira vista, a tabela apenas confirma o que já se sabia sobre os estudantes do IVL, minoritariamente interessados na música erudita. Alguns especificam seus repertórios inscrevendo-os em períodos histórico-estilísticos consagrados: barroco, medieval, renascentista, modernos russos. No desenho de círculos concêntricos proposto por Nettl, tais repertórios ocupam uma posição ligeiramente deslocada do centro. Do ponto de vista dos estudantes, as especializações são escolhas estilísticas relacionadas com projetos de carreira e de construção de identidades pessoais no campo da música. Ao distinguir, na massa de repertórios que o leigo chama eruditos ou clássicos, aqueles que mais apreciam ou que melhor se ajustam a suas habilidades, revelam o gosto formado que permite escolher. Simultaneamente, estes alunos distinguem-se dentro da totalidade de estudantes. A opção por repertórios que têm como apreciadores não o "grande público" da ópera e da música clássico-romântica, mas músicos e estudiosos, repertórios que, em alguns casos, implicam o 
uso de instrumentos "históricos" menos acessíveis (como o alaúde, a viola da gamba) e a relação com mestres conhecidos por sua especialização revelam a orientação para um círculo cultural relativamente restrito.

Contrariando a tendência de concentração na Licenciatura, os que tocam repertórios eruditos (genéricos ou específicos) são, geralmente, alunos dos bacharelados de instrumento e canto, cursos cuja própria organização canaliza a prática para tais repertórios. São representados, pelos alunos, como cursos nos quais só se estuda música clássica, cujos professores podem, eventualmente, rejeitar as incursões no popular. As possibilidades de atuação profissional praticamente limitam-se a coros e orquestras, além, é claro, da onipresente atividade como "professor de música". A limitação é ainda mais severa para os pianistas, que não contam com a alternativa da profissionalização em orquestras.

Num outro ponto da tabela, encontram-se as referências a repertórios "próprio" e "inédito", indicativos do valor atribuído à produção de uma obra "assinada", mesmo por quem não é compositor: como membro de uma banda dona de um estilo original ou como cantor que arregimenta autores e instrumentistas em torno de seu potencial de interpretação ou, ainda, como arranjador que dá roupagem original a certas obras, estes músicos encaram as carreiras como trajetos na direção de uma individualização ideal. Dificilmente realizam-se como executantes de música alheia ou colaboradores de um projeto musical com o qual não se identificam. Os espaços sociais de atuação da maioria dos estudantes (bar, restaurante, casa noturna, orquestra, estúdio) recrutam instrumentistas e cantores como intérpretes de repertório sobre o qual têm pequeno controle. Em alguns casos, o que se impõe é "o que está tocando nos rádios" naquele momento. As oportunidades para mostrar um trabalho próprio - composições, arranjos, improvisação instrumental, interpretação de repertórios selecionados pelo próprio intérprete - são menores, de sorte que as músicas próprias e inéditas configuram para muitos um ideal distante. Sobre instrumentistas que tocam em restaurantes, disse um baixista, aluno da Licenciatura: “... devem ganhar razoavelmente, mas, musicalmente, você tem que ficar tocando as músicas da onda, todo dia fazendo o mesmo trabalho...".

Da mesma forma como escolhas de estilos históricos têm valor distintivo, o repertório próprio é valorizado na mesma medida em que se valoriza a autonomia do músico na organização de sua carreira. Neste sentido, é significativa a única menção à "música de mídia" que apareceu nos questionários 
examinados. Longe de revelar que apenas um aluno dentre os consultados reproduz o que "está na onda" - muitos fazem-no para ganhar a vida -, mostra que esta prática profissional dificilmente é assumida como central.

A chamada música instrumental é prestigiada como a nata do popular. Associada a músicos "anfíbios" que atuam também no circuito erudito, evoca um refinamento do gosto, a posse simultânea dos saberes escolares e das habilidades consideradas típicas do músico popular. Trata-se de um tipo de música destacado por sua qualidade intrínseca, que reflete a "preocupação artística" de seus produtores. Sofre a marginalização imposta pelos meios de comunicação de massa e confina-se a espaços restritos e selos fonográficos alternativos. Suas dificuldades são atribuídas à organização do mercado, às grandes empresas fonográficas, quando não ao despreparo do público. A música instrumental figura como repertório difícil, que exige cultivo por parte de músicos e ouvintes, distante do gosto das massas. Produto dirigido a ouvintes musicalmente qualificados, estabelece uma relação entre músicos e seu público semelhante àquela que caracteriza a música erudita. ${ }^{14}$

As referências a repertórios populares sobressaem na tabela, combinadas ou não com repertórios eruditos. Aqui a concentração dos estudantes na Licenciatura é alta, confirmando, de certa forma, a constatação de um inchaço do curso decorrente da absorção de estudantes que são, antes de tudo, performers. Alguns gêneros populares são mencionados com muita freqüência - MPB, samba, bossa-nova e choro -, outros destacam-se por serem raros. O rótulo MPB constituiu-se, a partir dos anos 60, em oposição de um lado ao iê-iê-iê (posteriormente ao rock), de outro à bossa-nova, em debates que eventualmente retomavam a questão da autenticidade nacional e das raízes genuínas da música popular. Uma única referência ao rock e a preferência generalizada por MPB, samba, bossa-nova e choro remetem à hierarquização da música popular dominante entre os alunos, que, no entanto, podem indignar-se contra exclusões que percebem no ambiente escolar. A rebeldia diante de uma escola dedicada aos clássicos - é assim que alguns estudantes vêem o IVL -, que clama por maior atenção ao popular, é paralela a uma estrita categorização deste universo, com base em critérios de qualidade - relativos à estruturação interna

14 Em recente matéria sobre a música instrumental, uma espécie de mesa-redonda reunindo os nomes mais expressivos identificados com este segmento, dizia um dos participantes: "As pessoas entendem certos códigos mais simples, uma parte do povo é despreparada para ouvir uma música como a erudita ou a música instrumental brasileira" (Jornal do Brasil, 09/05/99, Caderno B, p. 1 e 4). 
das obras, por certo, mas também ao modo de recepção que estas encontram em diferentes segmentos do público.

A música popular praticada pelos alunos do IVL define-se contra um outro popular ${ }^{15}$ incapaz de identificar seus praticantes como músicos-artistas, potencialmente contaminador porque ligado aos setores do mercado que se pautam pelo critério quantitativo da vendagem e sucesso junto ao grande público. Conseqüência natural do gosto partilhado que raramente é chamado a explicitar-se porque raramente sofre contestação, a desclassificação de certos repertórios e autores é fruto de uma filtragem da música popular que seleciona aquela que os estudantes consideram digna. O bacharelado em Música Popular Brasileira surgirá talvez como instância autorizada para ditar níveis de qualidade, mas antes mesmo de sua implantação já operavam vetos silenciosos a músicas e músicos que despertam o riso quando mencionados, ou a revolta diante de coisas que "nem chegam a ser música".

O caso do rock - que não está entre os repertórios integralmente desclassificados - é curioso. A exposição a este tipo de música, assinalado apenas uma vez nos questionários, é imensa dentro do universo observado, onde há não só ouvintes de rock, mas também alguns "ex-roqueiros". Contudo, essa experiência é avaliada como adesão passageira a um tipo de música pouco satisfatório, o que resulta na negação explícita do rock como alternativa de carreira e na negação implícita de sua influência formadora. Tal tomada de posição decorre dos critérios de qualidade adotados pelos estudantes, que excluem tipos "fáceis", "superficiais", de música popular. Os que já passaram pelo rock contam como se cansaram de tocar peças cuja harmonia exige "poucos acordes", assim como se cansaram de repetir o mesmo repertório ao longo dos anos. Um deles fez sua conversão ao choro e, paralelamente, da guitarra elétrica ao bandolim, integrando presentemente um conjunto de chorões em vias de profissionalização.

O gosto pelo choro, bastante disseminado, também conduz à reflexão sobre as hierarquizações no universo da música popular. Há muito aclamado por músicos de formação erudita (Villa-Lobos vem logo à mente), o choro é música instrumental, o que de saída eleva seu status frente às formas cantadas e coreográficas, mais "populares" porque menos autônomas. Na ortodoxia purista da tradição clássico-romântica, servir à dança, à literatura ou a qualquer

15 Disse um dos entrevistados: “existe música popular e música popular". 
fim externo é curvar a música a uma funcionalidade, ferir a intransitividade da obra de arte (v. Todorov, 1977). O choro cabe bastante bem no figurino da música "pura", razão pela qual é possível tratá-lo com critérios de qualidade válidos para a música erudita.

A hierarquização que torna inaceitáveis para os estudantes certos tipos de música popular é análoga àquela que exclui todo o popular em nome das qualidades técnicas e estéticas da música erudita. Ao explicar suas escolhas, os estudantes invocam o domínio técnico pleno dos recursos instrumentais e vocais, solicitado apenas por repertórios mais exigentes, a possibilidade de crescimento do músico, incitando-o a ir do fácil e simples ao difícil e complexo (tocar sempre a mesma coisa é cansativo e indica a estagnação do músico), a individualização pela via da autoria ou conquista de um perfil estilístico original, a liberdade face às pressões extramusicais - sobretudo pressões mundanas, como o aplauso garantido. As premissas cristalizadas em torno da música culta - não é mero entretenimento, exige audição concentrada, supõe um sentido de evolução (aumento da complexidade e capacidade expressiva) - encontram eco entre os estudantes que praticam música popular.

Tais premissas, integrais à ideologia romântica da arte e do artista, manifestam-se também quando os praticantes de música popular são convidados a falar sobre suas experiências profissionais. Como se vê na tabela, eles têm nos bares, casas noturnas e restaurantes - ou simplesmente "na noite" - o grande mercado que recruta seus serviços. Nenhuma idealização dos modos de vida boêmios, "não-burgueses", geralmente associados às atividades artísticas e à freqüentação da "noite", transparece nas conversas. Tocar na noite, na verdade, é objeto de uma dura avaliação. A condição de operário da música, às vezes mal-remunerado e com pouca capacidade de negociar contratos, é uma das razões de queixa. Outra razão, talvez mais importante, é a desvalorização do músico por um público pagante que não está interessado na qualidade propriamente artística do que ouve, e por empresários que procuram aumentar seus lucros com baixo investimento. Engajado na produção destinada a um público anônimo e leigo, portanto público inferior na hierarquia das legitimidades, o músico da noite ressente-se da ausência de uma recepção propriamente musical e do tratamento dispensado por patrões:

... na noite é... nos bares me sinto às vezes quase que prostituída tocando em bar [...] E pelo tratamento que é dado a você [...] O garçom é mais importante 
- não que o garçom não seja importante, mas cada um tem o seu espaço, o seu lugar, sabe?[...] E, e não é questão de estrelismo nem nada, é questão de condições de trabalho, né? (aluna da Licenciatura).

A valorização da música gratuita, não-funcional, e a demanda de um público interessado são partilhadas por muitos estudantes, quer se dediquem à música erudita ou popular. Tocar na noite é uma "escola", como salientou um aluno, um intenso aprendizado que deve conduzir, entretanto, a outros patamares de carreira, a menos que se queira "ficar velho tocando em bar". Outro estudante, saxofonista e flautista, ressalta a importância que sua ampla experiência em orquestras de bailes teve para o conhecimento da música brasileira. Mas estes músicos da noite não enfeitam a vida boêmia com o glamour que ela costuma ter para certos setores da sociedade. Ao contrário, a rotina de bares e restaurantes pode ser vivenciada como desgastante artística e financeiramente. Um depoente lembrou que mesmo um "puta pianista" como Luizinho Eça "morreu pobre". Por isso, o formato de recital, que mais dignifica o músico, deve ter vigência na música popular também:

... eu prefiro, então, tocar em lugares tipo o [Centro Cultural] Banco do Brasil, essas coisas, em que as pessoas já vão sabendo o que vão escutar e vão para escutar, elas não vão lá pra paquerar não sei quem, e por um acaso tem música. Eu prefiro, eu prefiro, não que eu não faça isso, mas eu prefiro, se eu pudesse escolher... (aluna da Licenciatura).

Ainda convém distinguir experiências musicais na "noite". Tocar num restaurante pode ser uma experiência desalentadora de sujeição a um público sem gosto musical, ainda que os ganhos não sejam ruins.

Em contrapartida, tocar em certos bares de Santa Teresa (bairro carioca freqüentado por intelectuais, estudantes, artistas) é apresentar-se diante de um público de "pares", no sentido em que o gosto musical de ouvintes e músicos guarda identidade. O ranking de músicas é estabelecido por suas qualidades intrínsecas, mas tem relação também - embora não se o diga - com o status cultural do público ouvinte.

A preferência por MPB, choro e bossa-nova, ao lado das menções isoladas ao funk, soul, blues, gospel e rock, mostra ainda a tendência a associar música popular a tradições reconhecidamente brasileiras (a única exceção é o jazz, o que merece investigação). Além de alguns alunos identificarem seu 
repertório simplesmente como "brasileiro", constata-se nas entrevistas a sinonímia entre popular e nacional, que repercute um dos principais temas da história do pensamento sobre a música no Brasil, pelo menos desde Mário de Andrade. Apesar do desgaste sofrido pelas propostas de nacionalismo artístico de maneira geral, no século 20, e apesar, ainda, da existência de uma produção musical reconhecida como brasileira e erudita, as falas deslizam do "popular" para o "brasileiro": 16

O que eu sempre percebi e vi na música popular eram as pessoas, os grandes talentos, vejo pessoas que pesquisaram dentro da raiz da música brasileira, as grandes pessoas que a gente conhece que ficaram famosas, né? [...] adorei cantar Bach num coro que eu cantava, era a música que eu mais gostava, porque eu achava lindíssima, e tal, mas isso para mim não é um canal de expressão... Como eu acho que é o [canal] direto, que é a coisa mais direta da música popular, né? Brasileira... (aluna da Licenciatura).

A própria escola parece inclinar-se pela produção nacional: atestam-no a criação de um curso de Música Popular Brasileira, bem como seus símbolos ostentados. Ao contrário das instituições que celebram os grandes mestres da música universal tornando visíveis seus nomes, bustos e outras representações iconográficas, o IVL sugere a veneração de mestres nacionais cuja escolha não deve ter sido ao acaso: Villa-Lobos dá seu nome à escola (por ele fundada) e à maior sala de recitais, Guerra-Peixe e Alberto Nepomuceno são homenageados batizando outras salas ocupadas por performances públicas. O jardim abriga o busto de Mário de Andrade, que mesmo não tendo sido compositor, assumiu a liderança intelectual da linhagem de músicos nacionalistas. Como nas escolas descritas por Nettl, o panteão local de músicos só incorporou compositores - não intérpretes -cuja obra é reconhecida como erudita. E significativo que pelo menos um deles evoque também a combinação harmoniosa entre interesse estético e científico pelo folclore e criação sofisticada, aspecto que a presença de Mário de Andrade só vem reiterar.

${ }^{16}$ Uma observação adicional: o único aluno que se referiu a um repertório popular latino-americano é equatoriano. Moêma Brito, em pesquisa sobre o currículo da Licenciatura, colheu depoimentos que também atestam a força de uma vertente nacionalista no IVL. Um dos ex-estudantes consultados por Brito (1990, p. 8) pedia a "nacionalização" do currículo musical: "O currículo terá que ter a cara do Brasil - menos informações e conceitos de música européia e mais profundidade naquilo que nosso país potencialmente possui.

Horizontes Antropológicos, Porto Alegre, ano 5, n. 11, p. 119-144, out. 1999 
Simultaneamente, estão ausentes, dentre os tipos de repertório, categorias que designam músicas "étnicas", embora algumas, como blues e soul, possam evocá-las. Apenas um estudante serviu-se da categoria "folclore" para identificar seu repertório, o que parece entrar em contradição com o interesse, reaceso ultimamente entre estudantes, pelas tradições orais. Há os que "sobem os morros" do Rio de Janeiro, circulam entre partideiros com seus cavaquinhos, freqüentam o jongo da Serrinha, incorporam os idiomas reunidos sob a denominação de "forró". Entretanto, "músico folclórico" não é, no Brasil, uma especialização profissional socialmente reconhecida. Artistas cuja obra é calcada em estilos da tradição oral (Luiz Gonzaga, por exemplo) são ditos populares. Pertence ao universo do folclore quem não transpôs a fronteira do anonimato e da música funcional desvinculada do mercado.

A multimusicalidade que penetra nas escolas norte-americanas, como mostra Nettl, é paralela ao multiculturalismo reivindicado por grupos que se identificam com base em nacionalidade e etnia. No Brasil, músicas indígenas e afro-brasileiras per se (caem na rubrica "folclore") não constituem repertórios disponíveis à escolha dos estudantes: não são concebidos como tipos autônomos, mas como fontes de inspiração e de variedade a serem exploradas em outro plano - erudito ou popular. Os estudantes negros, minoritários no IVL, poderiam ser candidatos à reivindicação de mais familiaridade com tradições afro-brasileiras, e talvez à especialização em torno de repertórios a elas vinculados. Entretanto, não há indícios convincentes de convergência entre identidade étnica e estilístico-musical. Nenhum dos entrevistados informou uma adesão religiosa aos cultos afro-brasileiros, como o candomblé, cuja música, portanto, só integra o leque de experiências dos alunos quando mediada pela bibliografia e discografia.

A ausência de repertórios "exóticos" (por exemplo, música indiana) também dá uma medida da forte inclinação por uma prática musical brasileira "nacionalizada", isto é, que não identifica exclusivamente grupos étnicos ou regionais.

Por fim, há os adeptos do repertório "sacro" ou "religioso", com preocupações distintas e carreiras peculiares. O coro canaliza a maior parte dos músicos das igrejas, como cantores, regentes, acompanhadores, embora existam também as bandas que absorvem instrumentistas. Seu engajamento no 
debate sobre a hierarquia de repertórios é menos evidente: na verdade, parecem ser um grupo pouco comprometido com o mapeamento do universo musical nos termos da dicotomia entre erudito e popular. Sua preocupação com uma música propriamente brasileira é algo que ainda não foi suficientemente investigado. Pensam sua prática em outros termos, opondo música religiosa à "música do mundo", em bloco, e aceitam a subordinação da produção cultural à religião. De fato, os agentes religiosos que têm autoridade nas igrejas protestantes tradicionais e evangélicas têm, simultaneamente, poder de censura moral e estética sobre a atividade musical dos fiéis: "Quando eu era de música evangélica $[. .$.$] existia um certo preconceito de eu ir tocar a música do mundo,$ os mais fechados criticavam, ninguém impunha, mas todo mundo te colocava uma certa culpa" (aluno da Licenciatura).

Nicho de produção musical presa à esfera da religião, que contradiz a autonomia da vida propriamente cultural nas sociedades modernas, o repertório sacro é composto e interpretado também por estudantes que buscam formação superior no ambiente laico da escola. A lógica que orienta sua participação simultânea nesses dois "mundos" tão diversos deve ser olhada com mais cuidado. Acatando a doutrina de suas igrejas no que tange à música ao mesmo tempo em que freqüentam uma escola leiga, alguns são totalmente absorvidos pelo mercado musical que as igrejas oferecem. Outros vêem, no mercado mais amplo, oportunidades de exercer a profissão de músico dissociadas da vida religiosa. Neste caso, flexibilizam as restrições estéticas das igrejas, as quais se traduzem, por exemplo, na evitação de músicas evocadoras da cultura afro-brasileira: “... na igreja existe até um pouco de preconceito com ritmos brasileiros, como se associasse samba à coisa de macumba, não é uma coisa clara, mas existe um certo preconceito" (aluno da Licenciatura). Se a vida musical começa a ampliar-se para além dos círculos das igrejas e se o músico move-se entre várias igrejas com graus distintos de austeridade e controle moral e estético, a pressão mundana pode sobrepor-se.

As observações resumidas nas páginas anteriores bastam para mostrar a variedade de experiências dos estudantes de música do IVL. Os grupos mais numerosos e de mais visibilidade estão orientados para a música popular e para a classificação hierárquica - contestada - que a inferioriza perante a música erudita. Entretanto, como a expressão música popular recobre repertórios 
que estão numa perigosa fronteira com a produção rasteira da indústria cultural, os estudantes precisam reiterar a qualidade intrínseca, musical, e o valor artístico do que fazem. O curso de Licenciatura tem sido a porta de entrada para esses músicos que vêem a escola como um establishment erudito que discrimina injustamente determinadas obras e autores. Confrontados com a hierarquia vigente na escola, recorrem aos valores dominantes e apropriam-se deles para serem reconhecidos como artistas também. Isto significa que suas possibilidades de advogar um verdadeiro pluralismo estético está limitada, não por sua prática, mas pelas formas de organizá-la conceitualmente, com categorias e critérios de seleção aceitáveis no campo artístico. Em outras palavras, muitos estudantes têm e desejam ter experiências e formações variadas que incluem o conhecimento escolar dos clássicos e as "levadas" do popular, a audição concentrada e o contato distraído, a música pura e o divertimento da dança. Entretanto, quando se trata de pensar suas próprias carreiras como músicos profissionais, têm que reivindicar para si a dignidade de artistas.

\begin{tabular}{|l|c|c|c|c|c|c|}
\hline \multirow{2}{*}{ Curso } & \multicolumn{3}{|c|}{$\begin{array}{c}\text { Alunos cursando } \\
1998 / 2^{\circ} \text { semestre }\end{array}$} & \multicolumn{3}{c|}{$\begin{array}{c}\text { Alunos cursando } \\
1999 / 1^{\circ} \text { semestre }\end{array}$} \\
\hline & masc $\%$ & fem $\%$ & Subtotal & masc \% & fem \% & Subtotal \\
\hline Licenciatura & $142=68 \%$ & $65=32 \%$ & 207 & $145=65 \%$ & $176=35 \%$ & 221 \\
\hline Instrumento & $53=64 \%$ & $29=36 \%$ & 82 & $61=64 \%$ & $34=36 \%$ & 95 \\
\hline Composição & $17=94 \%$ & $1=6 \%$ & 18 & $20=95 \%$ & $1=5 \%$ & 21 \\
\hline Canto & $8=50 \%$ & $8=50 \%$ & 16 & $9=52 \%$ & $8=48 \%$ & 17 \\
\hline Regência & $9=90 \%$ & $1=10 \%$ & 10 & $11=91 \%$ & $1=9 \%$ & 12 \\
\hline $\begin{array}{l}\text { Música } \\
\text { Popular } \\
\text { Brasileira }\end{array}$ & $15=83 \%$ & $3=27 \%$ & 18 & $24=75 \%$ & $8=25 \%$ & 32 \\
\hline Total & $244=69 \%$ & $107=31 \%$ & 351 & $270=67 \%$ & $128=34 \%$ & 398 \\
\hline
\end{tabular}

(Fonte: Informações Estatísticas da Secretaria dos cursos do CLA).

Distribuição dos alunos por curso e por sexo cm 1998/99. 
A Licenciatura concentra mais da metade dos alunos do IVL O curso de Música Popular Brasileira, apesar da implantação recente, já congrega mais alunos do que Canto ou Regência. Alunos do sexo masculino predominam em todos os cursos, exceto Canto. A alta concentração de homens em Composição e Regência reflete e reforça a tendência de produzir compositores e maestros do sexo masculino. A mesma tendência masculina vem sendo observada no bacharelado de Música Popular. Pode-se supor que o novo curso reduz o "inchaço" da Licenciatura reduzindo o número de alunos do sexo masculino, que passam a se encaminhar para a Música Popular. Permanecem procurando a Licenciatura estudantes do sexo feminino, cuja "vocação" para o magistério primário e secundário faz parte das representações tradicionais das ocupações apropriadas aos gêneros. Esta hipótese deve ser testada quando estiverem disponíveis dados sobre a procura global da Licenciatura nos próximos anos (tanto por meio do vestibular quanto por meio de transferências internas, que contribuem para atestar o reencaminhamento dos alunos "desviantes", da Licenciatura para a Música Popular). Alguns estudantes intuem que este último será o curso de maior crescimento no futuro imediato.

\section{Referências}

BOURDIEU, P. A economia das trocas simbólicas. São Paulo: Perspectiva, 1982.

BRITO, M. R. de. Reflexão sobre o curso de Educação Artística, Licenciatura Plena, Habilitação em Música, do Instituto Villa-Lobos da Uni-Rio. Rio de Janeiro, 1990. Relatório mimeografado.

CARVALHO, J. J. de. O lugar da cultura tradicional na sociedade moderna. In: SEMINÁRIO FOLCLORE E CULTURA POPULAR: as várias faces de um debate. Rio de Janeiro: IBAC, 1992.

CHANAN, M. Musica practica: the social practice of Western music from Gregorian chant to Postmodernism. London: Verso, 1994.

CHARTIER, R. "Cultura popular": revisitando um conceito historiográfico. Estudos Históricos, Rio de Janeiro, v. 8, n. 16, p. 179-192, 1995. 
DeNORA, T. Beethoven and the construction of genius: musical politics in Vienna, 1792-1803. Berkeley: University of California Press, 1995.

MIDDLETON, R. Studying popular music. Milton Keynes: Open University Press, 1990.

NETTL, B. Notes. In: NETTL, B. The Western impact on world music: change, adaptation and survival. New York: Schirmer Books, 1985.

NETTL, B. Heartland excursions: ethnomusicological reflections on schools of music. Urbana: University of Illinois Press, 1995.

SEEGER, A. Why Suyá sing: a musical anthropology of an Amazonian people. Cambridge: Cambridge University Press, 1987.

TODOROV, T. Théories du symbole. Paris: Seuil, 1977. 